The Geneva Papers on Risk and Insurance, 17 (No. 62, January 1992), 119-142

\title{
Integration of the Disabled in the Work Process: The Dutch Policy ${ }^{1}$
}

\author{
by Lei Delsen and Saskia Klosse ${ }^{2}$
}

\section{Introduction}

\subsection{Disability - the concept}

It is estimated that there are 1.6 million disabled persons living in the Netherlands; of these, $90 \%$ are affected by physical impairement and $10 \%$ by mental impairement. In the Netherlands a broad interpretation is given to the concept of disability or handicap. In the scientific sense, it is almost always synonymus with diminished capacity, the latter in relation to work and income. One is, to a greater or lesser extent, unfit for work when one's earning ability is impaired or, put another way, when one's capacity to generate an income through work is diminished. Income comparison is used to determine whether or not this has occurred: an individual's pre-disability earning is compared with the income that he or she may, despite impairement, still derive from an appropriate occupation. If the comparison reveals a loss of income, one speaks of diminished earning ability or occupational disability. Depending upon the degree of loss of income, one speaks either of total disability (where no, or only a minimum, income can be derived from work) or of partial disability (where some sort of income can still be earned).

One significant consequence of this method is that under the Dutch policy for integration in principle no specific distinction is made between physical and mental handicap; in most instances both are deemed to constitute impairement in some measure and, as such, both types of handicap fall into the same general category of "occupational disability". Under Dutch law a single system applies to all forms of disability as far as the securing of replacement incomes and labour-force reinsertion are concerned. In the matter of occupational disability, therefore, the physically and mentally handicapped are on an equal footing.

1 Paper delivered to the international congress "Vieilissement et Travail", St-Amand-Montrond (Cher), France, 25-27 October, 1990. The authors would like to thank Mr M. Mulvey for the translation from the french version.

2 Respectively of the Department for Applied Economics, Faculty of Politicy Sciences, Nijmegen University, Thomas van Aquinostraat 1, NL-6525 GD Nijmegen, and the Europa Instituut, Utrecht State University, Janskerkhof 3, NL - 3512 BK Utrecht. 


\subsection{Disability and work}

Although Dutch law in principle treats the mentally and physically disabled as equals, there is, even so, a distinction - albeit a general one - between the two categories. It has to do with their respective positions on the labour market and is perhaps not without interest to a congress which has "disability and work" as its main topic.

The mentally disabled more often than not work outside the normal labour environment in what are called "social" or "protected" workshops, the mentally retarded more especially and former psychiatric patients having little chance of finding employment in the everyday world of work. Moreover, research has revealed that the mentally disabled frequently work below their skill level. The physically handicapped by contrast are more likely to find employment within the normal work environment, it being not only the nature of their impairement but also the severity of the latter which will determine the handicapped individual's chances of finding a job (Delsen and Bemelmans, 1987). A fair number of the disabled are jobless involuntarily; for research has shown that $90 \%$ of the occupationally disabled in the Netherlands would accept work immediately if a job came their way. Work is clearly valued not only economically, as a source of income, but also socially because of the contact and opportunities for personal fulfilment it affords. The disabled miss the human contact and atmosphere of the work place, as well as the routine and life-goals it stands for. Research has shown that many feel very cut-off from the main stream of life and of no use to their fellows (Merens-Riedstra, 1983). Not only is there a higher incidence of unemployment among the disabled, but its duration tends to be above the labour-force average, and this adversely affects their chances of finding employment.

In view of the importance that the disabled attach to being able to work, this article proposes to describe what the Dutch authorities have done to promote the reinsertion of disabled workers into the normal work environment. "Reintegration" here refers to the measures taken to bring the disabled, who have been excluded from the work environment or are threatened with exclusion, back to the work place. We shall first describe the main disability insurances as exist in the Netherlands and the steps taken recently to limit the incidence of occupational disability within the labour force. Relevant to this policy are the government's reform of social security and its adoption in this connection of the Handicapped Workers Employment Act or WAGW; the main purpose of the latter being to make it easier for disabled job-seekers to find employment. We shall then go on to examine the Sheltered Employment Act or WSW and recent amendments to the latter, since the policies pursued under this act are particularly relevant to the mentally disabled. Its purpose is to secure appropriate protected employment for workers unable to find jobs in the normal work environment. We shall end with one or two conclusions.

\section{Disability insurance}

\subsection{Legal framework}

The main statutory provisions relating to (prolonged) occupational disability in the Netherlands are the General Disability Benefit Act (AAW) and the Disability Security Act (WAO). ${ }^{3}$ Both these acts concern persons employed in the private

${ }^{3}$ For short-term occupational disability there exists the Sickness Benefit Act (ZW) which provides employees with a replacement income $(70 \%$ of the last wage earned) during the first year of disability. 
sector ${ }^{4}$ The AAW is a social insurance which entitles any resident between the ages of 18 and 65 years to a minimum social allowance. ${ }^{5}$

This allowance bears no relation to the pre-disability income, but is linked to a fixed sum, itself based on the (gross) minimum wage. The level of the allowance varies with the degree of disability. Where the latter is $100 \%$, the AAW benefit is in principle $70 \%$ of the minimum wage, or less as the degree of disability diminishes. One of the requirements, in addition to residence at the time of onset of disability, is that the individual should have suffered the disability for 52 consecutive weeks. Moreover, for one whole year prior to the onset of disability, the individual concerned must have derived a given income from, or in relation to, the exercise of an occupation in business or a profession, ${ }^{6}$ and the disability itself must be at least $25 \%$.

The WAO is an employees' insurance which entitles them, until their 65 th year, to an indemnity based on the last wage earned. The level of this indemnity depends also on the degree of disability expressed as a percentage which is itself calculated according to an arithmetical formula based on income loss. If, therefore, the individual was earning 3000 florins prior to disability and, subsequently, through an appropriate occupation, was still able to earn 2000 florins per year, the disability percentage would be $33 \%$ ([3000-2000] : 1000). ${ }^{7}$ If the disability was $100 \%$, the indemnity would amount to $70 \%$ of the pre-disability wage; as the disability diminishes, so also does this percentage. Entitlement to this indemnity requires that the individual be in gainful employment at the time of onset of disability and have sustained it for 52 weeks. As with the AAW, with the WAO there also exists a minimum disability level, which in this case is not 25 but $15 \%$. If earnings loss is so small as to be below this percentage, then no disability is deemed to have occurred. Another difference is that with the WAO there is no requirement regarding a given wage level prior to the onset of disability.

Since employees are also residents, in theory both benefits, the AAW and the WAO, apply. To avoid duplication, however, the law stipulates that where there is entitlement to the WAO, the AAW shall not be awarded, which in general means that the disabled are eligible for one or other benefit.

\subsection{The legal framework - its significance for the physically and mentally handicapped}

For the physically and mentally handicapped as much the AAW as the WAO can be important. If physical or mental disability occur at an early age, use may be made of the

\footnotetext{
${ }^{4}$ In addition, there exist special diability pensions for civil servants (General Civil Pensions Act, ABP), for railway staff (Railway Pensions Act, SP) and for military personnel. The conditions for payment and levels established by the Acts are broadly similar to those of the WAO. These laws affect approximately $10 \%$ of the people receiving a disability benefit in the Netherlands. These categories will not be considered in what follows.

${ }^{5}$ In the Netherlands, the minimum social allowance is set at $100 \%$ of the minimum wage for households, $90 \%$ for single parents, and $70 \%$ for persons living alone; the minimum wage is about 91 florins per day (approximately $270 \mathrm{FF}$ ).

${ }^{6}$ This works out at approximately 4,400 florins (48 times the minimum daily wage); for the "early handicapped", i. e. persons who became disabled before their 17 th birthday, this requirement need not be met.
}

${ }^{7}$ In calculating the percentage of occupational disability under the AAW, the same system is used. 
AAW basic benefit. It should be remembered that the AAW benefit is claimable only by disabled persons who have reached their 18 th year $^{8}$ and comprises an indemnity at the minimum subsistence level. If disability occurs while the individual is in the service of an employer, the WAO benefit may normally be claimed, and its level will depend on the wage loss resulting from the disability, expressed in terms of a given disability rate. Now, since the benefit is a percentage of the last wage earned, the latter will be decisive in determining the level of the benefit in question. In the case of individuals on modest earnings, the factors just mentioned mean that the income situation of a person eligible for the WAO benefit will not differ greatly from that of a person handicapped as of an early age and entitled to the AAW indemnity. As the level of the last wage earned increases, and with it the level of subsequent income loss, differences in the income situation of these two categories may begin to appear; for those suffering from mental disability as of an early age and who, if they have ever worked at all will have done so at an extremely low wage level, this will in practice mean that relatively speaking they will be receiving a benefit substantially lower than that awarded to physically disabled persons who have in fact already worked at relatively high wage levels.

Another significant consequence of the current system in the Netherlands is that the very same handicap may in one case give rise to occupational disability and not in another with evident implications as far as benefit awards are concerned. It might even be argued that the existing regulations discriminate between the two categories of disabled individuals involved. An accountant, for example, who, following a serious traffic accident, had to have his leg amputated, might well be able, with certain adjustments, to continue working more or less as before. The likelihood of significant loss of income due to disability would thus be minimal. In all probability the accountant would be deemed to be suffering a degree of disability of less than $25 \%$ and would as such not be eligible for WAO benefit. And this situation would obtain for as long as he were able to derive an income from his occupation. Should, however, the accountant lose his job and not be able to find another, the position would change considerably. He would then be obliged to rely on the far less favourable unemployment benefit which would in the long run result is his receiving benefit at the minimum subsistence level. A ballet dancer, on the other hand, who has been dancing since the age of 16 and who sustains the same accident with identical physical consequences at the age of 30 , would in respect of the self-same handicap be deemed $100 \%$ occupationally disabled at least for as long as she was unable to find an appropriate substitute occupation from which she could derive an income. Normally speaking, she would thus be spared the hardship of having to settle for benefit at the minimum subsistence level. These two examples clearly illustrate the possible consequences of a system based on income loss which takes no account of the severity of the handicap.

Ultimately, for the mentally and physically disabled, it is important that under the AAW there should be provision for entitlement to certain special facilities. These might take the form of adjustments in the work place to make it easier for the disabled to exercise certain occupations. Thought might also be given to the idea of improving transport facilities and living conditions in general. To qualify for such facilities, the disabled person does not necessarily have to meet all the AAW requirements for benefit award: the agethreshold of 18 years is not essential, nor is it required that an income be earned during the

\footnotetext{
${ }^{8}$ See article 6, subparagraph 9 , of the AAW.
} 
year preceding disability. Certain other conditions, on the other hand, must be met. The provision of such arrangements should basically be individualised and subject to medical recommendation. Moreover, routine general facilities are not provided for under the AAW, and income ceilings are established for acquisitions generally considered to be normal for certain income categories.

\subsection{Hidden unemployment}

One important issue which the Dutch system raises is whether, in establishing the degree of occupational disability, it is possible to take into account the effective chances an individual has of finding the sort of work that he or she is medically capable of performing. Were it is possible to account for such a variable, in cases where no suitable occupation was likely to be found, it could be assumed that, since the individual's earning potential was nil, the consequent income loss would be total and that as such the individual would be deemed $100 \%$ disabled.

The original AAW/WAO stipulations referred to the need for reflecting the disabled person's nil or diminished chances of finding employment. ${ }^{9}$ In assessing the degree of disability, therefore, the prevailing labour market situation was taken into account. In practice this led to beneficiaries, who from a medico-ergological standpoint were still capable of doing certain jobs, being declared $100 \%$ disabled when no suitable employment was available or when the individual concerned, although in principle willing to work, could find no employment. In the latter circumstance, it was assumed, in the absence of evidence to the contrary, that the individual's inability to find employment was caused by the disability. In both cases a total disability benefit could be claimed.

As unemployment increased in the Netherlands, this practice led to large numbers of the occupationally disabled being awarded the full disability benefit. In 1980 this was true of $84.6 \%$ of cases, in 1985 of $83.7 \%$, and by the end of 1988 this percentage had fallen to 81.6. In spite of this decline, currently most AAW/WAO beneficiaries are still declared $100 \%$ disabled.

The very large numbers of those awarded the full benefit, however, cannot be attributed solely to the provisions of the law and to the manner of their application. Mass unemployment and the consequent growth in the supply of able-bodied labour have had a significant part to play as well. Employers have in these circumstances tended to pursue selective employment policies, with the result that not only have the disabled been at a disadvantage as candidates for jobs but those already in employment have suffered as well. In any recessive situation, employers tend to raise productivity standards in order to offset labour costs (Bosch and Petersen, 1983 and Klosse 1990). In particular with older workers who have grown less productive, the WAO would appear to provide a useful way of masking lay-offs. ${ }^{10}$ Indeed, employers cannot off-load these workers without complying with complicated redundancy procedures, and employees themselves in a labour-market situation of this kind can more or less count on receiving until their 65 th year a benefit equal to $70 \%$ of their last wage.

${ }^{9}$ Article 21, subparagraph 2a, of the WAO, and article 12, subparagraph 2a, of the AAW.

${ }^{10}$ In 1986 over $50 \%$ of the original beneficiaries in the 55 to 64 year age-group were receiving a WAO benefit; this illustrates the fact that this benefit has functioned as a form of early retirement. In recent years, voluntary early retirement (VUT) has been used as an alternative to the WAO and unemployment benefit. 


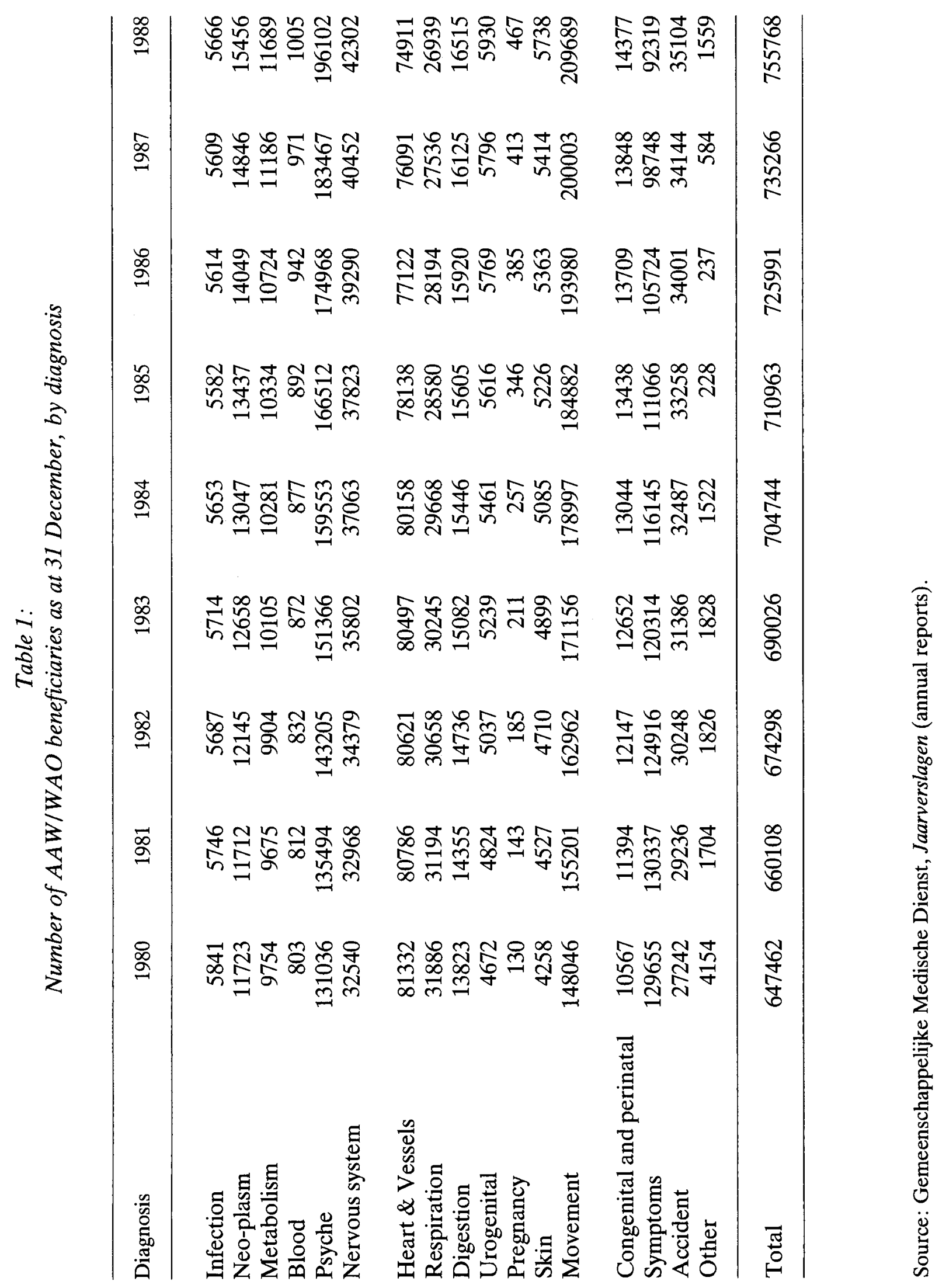


Another aspect which forms an important part of this overall picture is the medical one. Persons applying for disability benefit must obtain certification from an insurance doctor that their disability is due to sickness or infirmity. With the less well-defined conditions, and psychic disorders especially, this is not always an easy task. In such cases, doctors tend to give the patient the benefit of the doubt (Klosse, 1990). Table 1 shows that over time psychic disorders together with disturbances of the motor system have been the main causes of occupational disability. While in 1983 these causes accounted for $43.1 \%$ of awards to AAW/WAO beneficiaries, by 1985 this figure had risen to $49.4 \%$ (or almost one half) and by 1988 to $53.7 \%$.

\subsection{Growth in the number of the occupationally disabled}

The above-mentioned factors taken together have, on the one hand, led to an increase in the number of the occupationally impaired. In 1980, 647,462 persons were receiving an AAW/WAO benefit, but by the end of 1988 this figure had risen to 755,768 (see Table 1). Most beneficiaries were men, although their share has declined over time $(73.9 \%$ in 1980 and $70.4 \%$ in 1988). On the other hand, the factors described have also meant that a great number of persons were awarded the full disability benefit while being only partially impaired or partially unemployed. Estimates of the size of the hidden unemployment component in disability insurance in the Netherlands vary from between 15 to $50 \%$ of all beneficiaries. The. Dutch government estimates this component to account for $50 \%$ of total beneficiary-days (Delsen and Bemelmans, 1987).

Table 2:

GMD integration results, 1983-1988

\begin{tabular}{lrrrrrr}
\hline & 1983 & 1984 & 1985 & 1986 & 1987 & 1988 \\
\hline Private sector & 9976 & 8969 & 13327 & 17028 & 22800 & 23638 \\
Self-employed & 4303 & 3795 & 4793 & 3696 & 3700 & 6599 \\
WSW & 960 & 865 & 849 & 1040 & 1600 & 1030 \\
Unemployed & 19501 & 17335 & 22122 & 29867 & 32400 & 38871 \\
\hline Total & 34740 & 30964 & 41091 & 51631 & 60500 & 70138 \\
\hline
\end{tabular}

Source: Gemeenschappelijke Medische Dienst, Jaarverslagen (annual reports).

The state of affairs whereby partial disability can continue to combine with receipt of a full benefit until the age of 65 years stems in part from the fact that currently the disabled have enormous difficulties in returning to normal employment. The reason for the increase in the number of WAO beneficiaries is a structural one, since the number of those leaving the programme continues to lag behind the number of new entries (Bax, 1984). For many the WAO proves to be the end of the road, and Table 2, on the GMD's (Joint Medical Service) integration results, illustrates the extent to which this is so. Indeed, the GMD plays an active part in reinserting the disabled in the work process. Table 2 shows that approximately one half of the disabled remain jobless. Close on one third find jobs in the private sector and 
$8 \%$ become self-employed, with a tiny minority finding employment in the sheltered workshops established under the WSW. From Tables 1 and 2 it may, moreover, be deduced that the GMD's success in reinserting the disabled is limited, since it appears to affect less than $10 \%$ of $\mathrm{AAW} / \mathrm{WAO}$ beneficiaries.

With population ageing in the Netherlands and the increase in labour-force participation expected of women, the number of the occupationally disabled will for the time being continue to rise. This trend will become even more pronounced when opportunities for voluntary early retirement (VUT) are restricted. Estimates suggest that within ten years the number of the occupationally disabled in the Netherlands will have risen to 1 million. The cost of benefits will also increase, and it is this factor especially which has caused the government to make radical changes to its policy. In this connection, the social security reform of $1987^{12}$ and the related introduction in 1986 of the Handicapped Workers Employment Act are significant. We shall now examine the two bodies of legislation involved and then go on to discuss the efficacy of the policies pursued and make suggestions as to policy directions for the future.

\subsection{The social security reform of 1987}

The words "social security reform" imply that the relevant changes affected much more than merely disability insurance. In addition, for example, unemployment insurance was substantially modified and a number of new laws enacted. We shall nevertheless confine our comment here to disability insurance.

The modifications to the disability insurance system are closely related to the constant increase in the number of the occupationally impaired as also to the steady growth in the number of the partially disabled on full benefit. It was in respect of this latter phenomenon that change was needed most, the idea being to reduce the number of those with full-benefit awards suffering from partial disability only. ${ }^{13}$

It was decided to make this practice impossible, for the government had for some years disapproved of persons who were medically capable of work but who could find no employment being classified as suffering from a $100 \%$ disability. In principle these persons were no more than partially impaired and partially unemployed and for this reason should have been receiving an unemployment, and not a disability, benefit.

Thus a decision was taken in 1986. In a slack labour market, the position of the unemployed was found to be difficult. The longer unemployment lasted, the more negligeable was the likelihood of securing employment, and yet the individuals concerned were receiving a less favourable unemployment benefit. The benefit itself was limited in time and eventually turned into a social allowance. A partially unemployed disabled person

11 The GMD is a public institution, bound by law to advise agencies awarding, inter alia, benefits, on the level of disability (article 71 of the WAO); the GMD plays therefore a crucial role in the implementation of the WAO.

12 Prior to this reform, there had been another which was financially more significant. The WAO recognises seven classes of beneficiaries related to fixed benefit percentages; as early as 1985 these percentages had been reduced. The maximum WAO benefit was lowered from 80 to $70 \%$ of the daily wage; a comparable modification was made to the AAW at the beginning of 1987 when the maximum AAW benefit was lowered from 80 to $70 \%$ of the minimum social allowance.

13 Assuming a high percentage (50\%) of hidden unemployment, one may expect this reform to achieve substantial economies. 
suffering from partial disability, by contrast, enjoyed a benefit that was linked to the last wage earned and that in principle he would continue to receive until the age of 65 years; and it was only in the rather unlikely event of his managing to find employment that this situation would change. The government felt that this inequality in the treatment of the unemployed and the occupationally disabled could no longer be justified. It was consequently decided to repeal those provisions of the law upon which the preferential treatment of AAW/WAO beneficiaries was founded, ${ }^{14}$ which in practice meant removing the unemployment component from the WAO and AAW programmes. Technically speaking, this means that it is no longer possible in determining the degree of occupational disability to take the labour market consideration into account. This in turn means that whether or not a person through work that he or she is medically capable of performing can in reality earn an income is no longer relevant. Those who on 1 January 1987 were aged 35 years and under and who were in receipt of the full disability benefit had to undergo reassessment of their level of impairement according to new criteria. Moreover, new candidates for disability benefit had their impairment level established according to more stringent criteria.

\subsection{Impact of the reform of the disability progamme}

If a person is deemed disabled or partially impaired according to the most stringent rules for assessment and proves unable to find remunerated work comensurate with the residual occupational capacity thus established, a complementary unemployment benefit may be claimed. The maximum duration of the said benefit which is linked to the last wage earned depends on the individual's work record and may vary from six months to five years. After which, for a period of one year, the individual may claim benefit at the social minimum without, as would be the case for social welfare allowances, any income or capital assets test being required. At the end of that year, the individual may claim benefit under the new IOAW act (relating to guaranteed income for the senior and the disabled unemployed). This law also provides entitlement to a benefit at the social minimum, but in this instance, although the capital means of the beneficiary and of his or her partner are not taken into account, and occupational or work-related income is. This arrangement, therefore, differs slightly from the regulations governing social welfare benefit which in addition take account of the beneficiary's capital means.

In establishing the system, the law-makers, in order to avoid disability assessment becoming a mere exercise in medical diagnosis, left some latitude to those responsible for implementation to reflect as fully as possible the reality of the cases they encountered. To this end, they specified for explicit cases where work, which, on purely medical grounds, could be performed, was even so not to be taken into account and could not therefore be built into the income equation. It was essential to avoid the practice of calculating the percentage of occupational impairment on the basis of an income potential which one knew, a priori, could not in practice be achieved.

From the data currently available, it can be deduced that those responsible for implementation have made at least some use of this latitude. A shift in the total has occurred: there has been an increase in the number of partial disability awards to persons who previously would have been deemed to be suffering from total disability. In 1988, $20 \%$ were

14 The articles in question are: 12 , subparagraph $2 \mathrm{a}$, of the AAW, and 21, subparagraph $2 \mathrm{a}$, of the $\mathrm{WAO}$; at the same time subparagraph 3 from both these articles was removed. 
awarded partial disability as opposed to $10 \%$ in 1985 , and $30 \%$ were declared able-bodied as against $20 \%$ in 1985 . More than one half continue to receive the full benefit while in 1985 this proportion was two thirds. Yet in spite of this trend, the number of full AAW/WAO awards continues to be substantially higher than partial awards, and it is suggested that the estimated percentage of hidden unemployment was probably too generous. This much became clear, for example, from the reassessments made in 1987 and 1988 of beneficiaries who, at the time more stringent criteria were introduced, were aged 35 years or less. It was assumed precisely that this cohort of young AAW/WAO beneficiaries included a substantial number who had been wrongly awarded unemployment benefit. Nothing could be further from the truth, for, by the end of the reassessment period, it became clear that close on $80 \%$ had been deemed to be suffering total occupational disability. Hidden unemployment, therefore, accounted for only a relatively small number of cases.

\subsection{The Handicapped Workers Employment Act (WAGW)}

\subsubsection{The link between the social security reform and the WAGW}

The WAGW which was passed in 1986 can be seen as a further development of amendments to the AAW and WAO. The Act provides for a number of facilities designed to promote labour-force participation of disabled workers. It recognises that disabled workers constitute one of the most vulnerable occupational categories in today's labour market. In view of the potentially adverse consequences of the amendments to the AAW and WAO on disabled workers, it was felt necessary to strengthen their position on the labour market.

In the absence of such measures, the disabled might, owing to the more stringent awards procedure, be adversely affected by changes to the legislation. A number risk being granted a partial or full disability award while their chances of securing remunerated employment from a new employer would be minimal. As a result, many would have to claim unemployment benefit with all the consequences that that would entail.

The government took cognizance of this problem, and through the WAGW and related provisions it has sought to improve the market position of disabled workers by promoting their labour-force participation and thus increasing their opportunities for redeployment and social integration. In addition, an attempt is being made to reduce the number of the disabled having to claim social benefit.

\subsubsection{Eligibility for the $W A G W$}

It is striking that, in defining the WAGW target group, the notion of "handicapped employee" has been retained. Thus for the first time, the concept of "handicap" has been explicitly incorporated into Dutch legislation. From the description of the target group, however, it appears that the introduction of the concept was not designed to change the prevailing practice of assimilating "handicap" and "occupational disability".

According to the WAGW, the term handicapped person denotes an employee who (Delsen and Bemelmans, 1987, p. 7):

- under the WAO or AAW, is entitled to benefit;

- under the AAW, is entitled to a facility without which he or she could perform no work;

- under the $\mathrm{ABP}$, the law on railway pensions and the general law on military pensions, is entitled to a disability pension, or who, following sickness or infirmity, has ex- 
perienced difficulties in obtaining or performing a job, or who has been enabled to obtain or perform a job subsequent to special measures or arrangements being provided ("safety-net" category); for inclusion in this category a general decree of execution is required. 15

Originally there were misgivings about inclusions in this category since it was felt that the law overstepped its purpose by an excessive broadening of the target group. Nevertheless, because of political pressure, the group was filled at the end of $1989 .{ }^{16}$ Handicapped employee is also taken to include any worker who:

- suffers a wage reduction under article 8 of the WAGW;

- uses a special means of transport without which he or she would be unable to reach the work place;

who, for three years:

- moves from the WSW programme into the regular work force;

- has received training immediately before taking up employment in a recognised training institution;

and who, for one year: 17

- looses his or her AAW/WAO benefit due to employment.

In addition, there exists one other special category: handicapped workers may also be considered persons for whom an employer has made special arrangements or provided special facilities without which, due to sickness or infirmity, the employee could not perform his or her work. This measure should be viewed as a reward for employers who, by adopting a preventive policy, have enabled employees to avoid recourse to disability insurance. To prevent large numbers of workers falling within the scope of the WAGW because of this stipulation, the minister for Social Affairs was to lay down stricter requirement for inclusion in this category. Such requirements have so far not been forthcoming. Persons in this category therefore are still unable to claim the status of handicapped employees.

\subsubsection{WAGW instruments}

WAGW instruments are of two kinds. On the one hand, the law contains provisions designed to promote acceptance of disabled workers by their new employers. Reference should be made in this connection to the quota obligation and to the GMD's competence as a placement agency and we shall have more to say later about both of these. On the other hand, the WAGW also includes measures designed to favour the retention of jobs by

${ }^{15}$ By general decree of execution is meant a decision by the Crown following consultation with the Council of State (also termed a Royal Decree, KB); the effect of a general decree of execution is that of law.

16 See Royal Decree of 21 December 1989, Official Gazette 1990, 32.

17 This time limit is introduced, since it would be excessive to deem such persons as permanently disabled; the purpose of bringing such persons under this law is to promote their exit from the AAW/ WAO system and their integration into the WSW work process. It is a priori accepted that such groups have obvious difficulties in obtaining and performing work; the time limit is therefore designed to avoid recourse being taken to undesirable alternative solutions. 
disabled workers; and here, in turn, we should mention the obligation placed upon the employer to appropriately adapt jobs and the work situation and the possibility of there being a temporary reduction in wages. We shall be describing these instruments in detail and will at the same time take a brief look at some of the related and complementary measures within the AAW and WAO.

\section{a) The quota obligation}

So as to encourage employers to take on disabled workers, the WAGW acknowledges the possibility of obliging employers to make jobs available to a given percentage of disabled workers, with a view to retaining them. This "quota obligation", as it is termed, was originally seen as the lynch-pin of the WAGW system. Yet it should be stressed that even now no uniform statutory quota obligation is in force. At the outset, the idea had been to impose upon employers in the private and public sectors a uniform $5 \%$ quota requirement, but this was never in practice accomplished. At the time the law was introduced a voluntary quota system was settled for. To this end the law required the social partners to take steps to foster to the extent possible the reinsertion of the disabled by mutual agreement. It is only where such arrangements prove unsatisfactory that a general decree of execution can impose a quota requirement which may vary from 3 to $7 \%$ according to the branch or public service department concerned. Where a quota requirement has been imposed, should an employer fail to comply, the latter shall be liable to a fine of 10,000 florins per unoccupied post per year. If, on the other hand, an employer takes on more disabled workers than this quota requires him to do, he may be entitled to financial compensation amounting also to 10,000 florins per disabled employee per year. The calculation and disbursement of such sums is undertaken by the relevant professional association on the basis of information supplied by the employer. In order that the professional association be able to check that a quota obligation has been discharged, the WAGW requires employers to maintain proper records. Failure to comply with this requirement is also sanctionable.

Even though to date the voluntary system has not achieved much, there seems to be no great desire to impose compulsory quotas in the short term since the current minister for Social Affairs is far from being an unqualified supporter of such regulatory measures. Moreover, the net result of such measures might well be law evasion since the employers themselves do not appear to favour the idea. Indeed, in an attempt to avoid the situation where the authorities would force them to comply, they have recenly been at pains to make their own proposals for stemming the increase in the number of the occupationally disabled. Their proposals focus mainly on the "cost" of disability insurance and tend to neglect the interests of the disabled themselves. It has, for example, been suggested that their number be kept down by raising the statutory requirements for benefit eligibility. If the employers had their way, any person in adapted employment which generated one third of his or her previous income would no longer be eligible for AAW/WAO benefit. ${ }^{18}$ Neither would such persons qualify for the WAGW unless they were eligible for an AAW facility or met the requirements for membership of the "safety-net" category. On the other hand, employers do appear ready to exercise some self-restraint in the matter of laying-off the partially disabled. It has been suggested that workers with between 33 and $66 \%$ occupational impair-

18 This amounts to raising the disability threshold to $33 \%$, the current threshold for WAO being at least $15 \%$ and for AAW $25 \%$. 
ment should not be liable to lay-off except on very serious grounds. Where such conditions are not fulfilled, the employer would be bound to retain such persons on the work force and offer them an adapted replacement job. The suggestion appears to be an interesting one, but the partially disabled with no employer in the offing would be even less likely to find employment.

\section{b) Job placement}

The GMD, because of its job exchange potential, can play an important part in the task of reducing employer resistence to giving work to the disabled. The GMD, in establishing the degree of occupational disability suffered by the worker, has information about the latter's residual capacity. This information can be used to counter employer prejudice regarding the disabled worker's occupational potential. But the GMD can also inform employers about the available financial rewards for giving employment to the handicapped, for example should adjustments in the work place be necessary or with regard to possible wage reduction. ${ }^{19}$ In this latter connection, a number of new proposals have been put forward, designed to make employment of the disabled more employer-friendly or even to provide for compensation. Thought has, for example, been given to the possibility of a subsidy at a maximum of $20 \%$ of the subsidised wage to be paid over a 4-year period; this could be combined with a single start-up and/or support subsidy. And here the government has come up with an interesting proposal; namely, to pay those offering employment to the partially disabled a bonus equal to several times the gross monthly wage of the employee concerned. ${ }^{20}$

Since a fair number of AAW/WAO beneficiaries appear to have difficulties finding a job owing to inadequate levels of training, it is not without interest that the GMD is expected to receive over a five-year period a fixed budget which could be used for training purposes. The effect of such measures could be to encourage the employer to pass off workers trained in this way as disabled under the WAGW definition, and thus evade a compulsory quota requirement. In addition, attempts are being made to promote such instruction and training in the work place by allowing an employer when such arrangements are provided to pay workers below the statutory minimum wage. ${ }^{21}$

Given the generally low levels of training of AAW/WAO beneficiaries, reference should also be made to a recently tabled draft law which envisages bringing wage costs down to the minimum wage level. ${ }^{22}$ The purpose here is to improve the labour-market standing of the relatively untrained jobless; to qualify, the employee would have to be 23 years of age or more and have worked one third of normal working hours for a least three consecutive months. The reduction in wage costs would amount to 3,200 florins per year or 800 florins per quarter for wage-earners receiving the legal minimum wage and working full-time $; 23$ this would constitute a reduction in wage costs at the minimum-wage level of around $10 \%$.

${ }^{19}$ For example, see in this connection article 57 of the AAW and article 8 of the WAGW.

${ }^{20}$ If the employer dismisses a partially handicapped worker, he is bound to pay a contribution also equalling several times the gross monthly wage of the worker concerned; the idea of introducing a nofault system is still under discussion.

${ }^{21}$ See in this connection PS (parliamentary documents) 1989, page 633.

22 TK 1988/1989, No. 21.145, Official Gazette 1990, 330.

${ }^{23}$ For part-time workers this sum is reduced proportionally; the sums may be offset by social insurance tax bonuses. 
With its capacity to act as a labour-exchange, the GMD could draw employers' attention to the (financial) advantages just mentioned as a way of helping them to overcome their reticence about taking-on disabled workers.

\section{c) Adaptation of jobs and work conditions}

When an employee becomes handicapped, he runs the risk of loosing his job, for his employer may well believe that he is no longer capable of performing his work normally. The WAGW aims at obviating this situation by obliging the employer to adapt the work place and conditions to suit the disabled employees on the work force. ${ }^{24}$ Should the employer fail to comply with this obligation, he is liable to penal sanction. One would not, however, expect things to reach such a pass. If, for example, an employer has financial grounds for objecting to job adaptation, various solutions would be available. He could, for instance, claim compensation - from the relevant professional association - for the cost of such adjustment. ${ }^{25}$ If the claim were accepted, the extent of compensation would depend on a number of factors: the kind of facility provided or the impact of such adjustment on the undertaking itself. Rejection of the claim, on the other hand, would not signify that the employer was freed of his obligation to provide adjustment. He would merely be obliged to bear the cost himself and failure to do this might leave him liable to the penalty referred to above.

Individual facilities related to the specific handicaps of disabled workers (e.g. wheelchairs) are as a rule provided by the professional associations. ${ }^{26}$ Should an employer fail to give employment to a disabled worker requiring such facilities, he may be penalised. The professional association may in such cases claim an amount equal to the wage the worker would have received had he been taken on. ${ }^{27}$ The employer is thuswise obliged to take on the worker in question. Moreover such a procedure can only be applied when the employer has no valid grounds for refusal. Whether this is so, is decided on the merits of the case: the nature and organisation of the undertaking, the kind of work the employee is capable of performing and the sort of sacrifices the employer would have to make in rendering such employment possible. One cannot therefore assume that in all cases recruitment will be imposed on the employer, for, to some degree, the latter's interests are also taken into account.

\section{d) Wage reduction}

Employers are in principle bound by the WAGW to pay handicapped persons the same wage as able-bodied workers, for equivalent work performed over identical work hours. ${ }^{28}$ There is, however, one exception to this rule which is called "wage exemption" whereby the normal wage may in some measure be reduced. Such "wage exemption" is subject to the following conditions:

${ }^{24}$ Article 6 of the WAGW. WAGW.

${ }^{25}$ Pursuant to new article 57 of the AAW, incorporated at the time of entry into force of the

${ }^{26}$ Pursuant to article 57, subparagraph 1, of the AAW.

${ }^{27}$ Pursuant to new subparagraph 6 of article 57 of the AAW, incorporated at the time of entry into force of the WAGW; since then, a similar penalty may also be imposed during the application period of the Sickness Act, pursuant to article 30 of the ZW.

${ }^{28}$ Article 7 of the WAGW. 
- where, owing to the handicap, productivity is substantially below average;

- where a "boost" has been applied; i. e. a provision to scale up disability classifications by one category, if partially disabled workers accept jobs paying less than their residual capacity ;

- where both of the preceding conditions obtain. ${ }^{29}$

Whether productivity is substantially less than average can only be judged on the basis of work actually performed. The "boost" is thus related to the condition that the employee derives - or will derive - from the occupation as performed a wage which is lower than what that employee would have earned from the work of which he or she is medically capable. A combination of the wage exemption and the "boost" may thus be used prior to a post being actually taken up. In relation to job placement, then, the availability of wage reduction may act as an incentive to employers to take on disabled workers. For the disabled themselves, this reduction needs not be seen as a disadvantage since it can be offset by an increased disability benefit.

In principle, use may be made of this measure over a two-year period, after which the situation must be reviewed. At this point, the employer must either pay the full occupational wage or have the wage exemption extended for a maximum of two additional years. For the disabled employee, payment of the full occupational wage signifies that the disability benefit will fall to match the real level of impairment. Should the combined "wage exemption / boost" arrangement be extended, the situation remains unchanged.

Wage exemption is not granted automatically. An application must be addressed to the professional association which will then seek the GMD's opinion. An application may be made by employer or employee, as also by the GMD itself which may use this facility in connection with its job-placement function. It is unfortunate that, when combined with a "boost", the margin for wage reduction is not very great, roughly, that is, $7 \%$ of the predisability wage. There are, however, plans for widening this margin to about $14 \%$ of the last wage earned, something which may well increase the number of uses to which this facility can be put.

\section{e) Protection against lay-off}

Despite the measures designed to make employment of the disabled more employerfriendly, it must be stated that the disabled without jobs are in a far more vulnerable position than those still under contract. Employers who are not attracted by the offer of financial compensation remain entirely free to fill their vacant posts with able-bodied workers and, in so doing, merely run the risk of being penalised. Should, however, an employer wish to terminate an existing employment contract, the position is by no means as simple. Firstly, Dutch law stipulates that a contract of employment may not be broken during the first two years of disability due to sickness. Other forms of termination - non-renewal or dismissal - are even so permitted. In examining the grounds for dismissal, an attempts is however always made in applying the law to determine whether sickness is the ground for the lay-off. If it is, termination of the contract will almost invariably not be permitted.

${ }^{29}$ Article 8 of the WAGW; the "dispensation" is governed by article 33a of the AAW and article 44 a of the WAO. 
Prior to July 1986, leave to lay-off two years after the onset of disability was frequently granted. With the coming into force of the WAGW, however, limits were set to this facility. In principle lay-offs will not be authorised even after two years of disability in cases where an employer is still in a position to offer adapted employment. And to the extent possible, this rule also applies to non-renewal of contracts. It is in this way possible to prevent an employer using non-renewal as a way of evading the more stringent lay-off authorisation procedure. A WAGW evaluation survey reveals that employers are attempting increasingly "to off-load in this way workers who have become the victims of disability". As a general rule, this subterfuge will not be successful unless the employer can prove that there exists no place in the undertaking for the disabled worker in question.

For disabled workers, this regulation (combined with other WAGW provisions) has led to a significant strengthening of their position. Such provisions, in so far as is possible, safeguard the continuity of the employment contracts of disabled workers which in turn maximises their chances of participation in the work process.

\section{Sheltered Employment Act (WSW)}

\subsection{Legal framework}

Unlike the AAW and WAO, the WSW or Sheltered Employment Act is intended to be implemented by local authorities and seeks to provide employment under appropriate conditions to "persons who are capable of working, but for whom, over a substantial period of time and for reasons of a personal nature, an opportunity to work under normal conditions has not (yet) arisen". According to this definition, close on 110,000 persons are eligible for jobs in sheltered workshops (Stoks, 1990). In such workshops, the individuals concerned perform adapted work designed, in so far as is possible, to preserve, re-establish or enhance occupational capacity. In addition to being a source of employment, sheltered work is also intended to function as a facility for rehabilitation. The WSW recognises three types of occupational domains: industrial (manual) work, cultural and civil-technical work and administrative work, offering respectively in excess of 50,30 and $16 \%$ of jobs. ${ }^{30}$ It, in addition, provides for placement to jobs in open employment.

The WSW contains no very precise definition of "handicap". Persons suffering from physical, mental or other disabilities who are unable, or no longer able, to find employment in the everyday occupational world, are all eligible for sheltered work. Candidates must be aged under 65 years. Even after take-on, employers remain bound to assist with placement to jobs outside the sheltered workshop, although in practice transfers to the regular work process are rare. In 1988, $310 \mathrm{WSW}$ employees transferred to open employment, ${ }^{31} 5 \%$ or less, that is, of total exits.

When classified by disability, the physically handicapped form the largest group $(44 \%)$, then the mentally retarded $(31 \%)$, in third place those suffering from psychic disability $(16 \%)$, and finally employees with disorders which have not been finally diagnosed or are unclassifiable $(10 \%)$. During the 80 's, the number of persons suffering from diseases of the motor system increased, and the number of physically handicapped remained

30 Over time these proportions have remained unchanged.

31 Exit to open employment concerned 163 persons in 1984, 210 in 1985, 318 in 1986 and 264 in 1987 (data supplied by the Ministry for Social Affairs and Employment). 

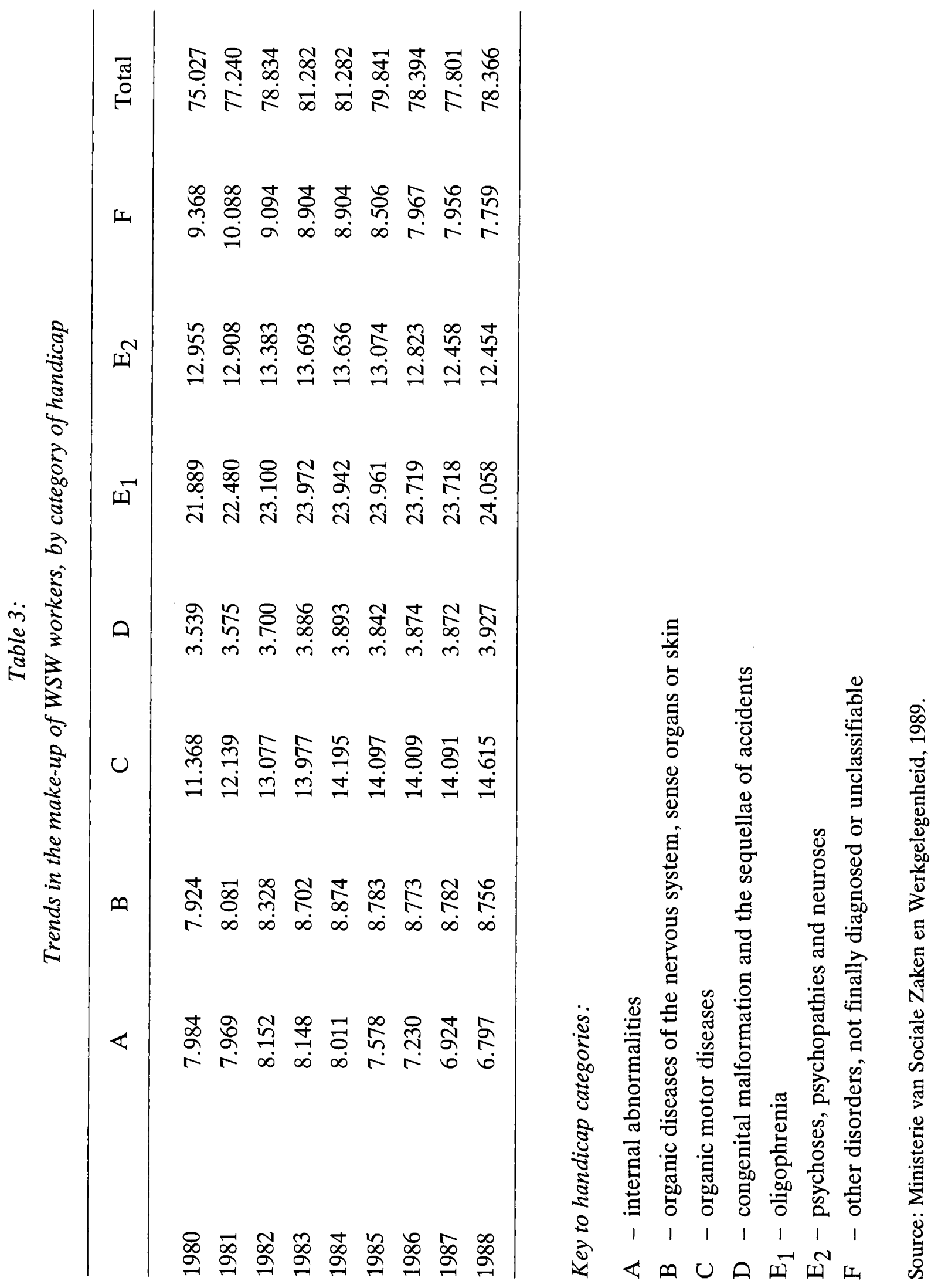


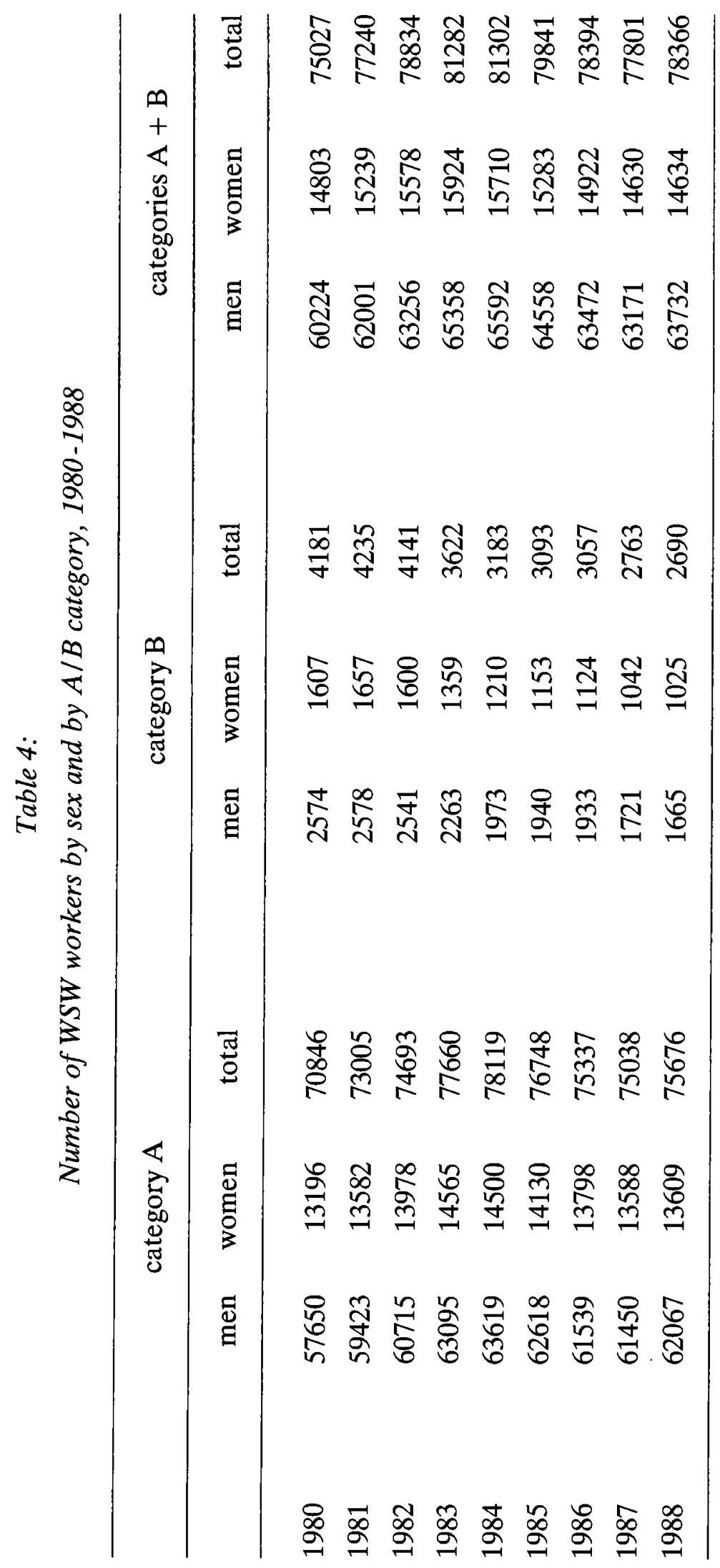

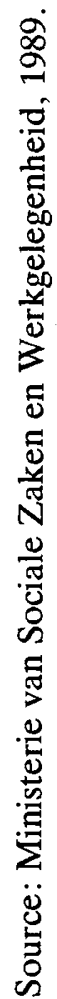


unchanged in absolute terms and, in relative terms, diminished. The number of mentally retarded grew in both absolute and relative terms (see Table 3). These figures illustrate the high proportion of the mentally handicapped in the WSW programme and hence the significance of the Act for their integration in the work process.

Most WSW beneficiaries are aged between 25 and 55 years and the share of this age group increased from $69.2 \%$ in 1980 to $78.6 \%$ in 1988 . This increase was due more especially to the steep rise in the number of WSW workers in the 35 to 44 year age group, the share of this group having risen from $21.1 \%$ in 1980 to $28.3 \%$ in 1988 , making it the largest in the WSW work force, ahead of the 25 to 34 year age group whose share is $27.1 \%$. Most WSW workers are male, their share having increased slightly from $80.3 \%$ in 1980 to $83.4 \%$ in 1988 (see Table 4).

WSW employees are divided into two categories according to their ability to perform productive labour:

- category A comprises those employees who, in an adapted work situation, are capable of working normally without disturbing the atmosphere of the work place. For identical or similar occupations, their productivity level must be at least one third of what can reasonably be expected of able-bodied employees in the normal work process;

- category B is reserved for employees who (for the time being) cannot attain a preestablished level of productivity, but whose well-being depends on the availability of appropriately adapted employment.

A shift from category $\mathrm{B}$ to $\mathrm{A}$ is by no means impossible. ${ }^{32}$ The conclusion of a contract of employment governed by the WSW is an available option. Following recruitment, there is a two-month probation period which may be twice extended. For category B workers, there is an instruction and training period of up to one year prior to recruitment.

Depending on the work performed, category A employees are divided into 10 wage groups, a wage-scale being attributed to each group. Each year a wage increment is awarded until the ceiling of the wage-scale in question is reached. Employees are paid at least the statutory minimum wage (for young workers). For category $\mathbf{B}$ employees, there exists a separate wage-scale, the sums paid being lower than the statutory minimum wage. The standard work week is 38 hours. As a general rule, WSW employees work 40 hours, the difference being offset by additional leave.

Approximately 15,500 WSW workers (20\%) receive an AAW/WAO supplement in addition to their WSW wage.

\subsection{Limiting the growing number of WSW beneficiaries}

Since entry into force of the WSW, sheltered work has grown considerably. Table 4 shows the growth trend in the number of WSW employees since 1980, in which year they totalled $75,027.33$ In 1984 this figure rose to 81,302 , the increase being in part due to the labour market situation. Because, above all, of the vague criterion "for reasons of a personal nature" in the standard profile for candidates for benefit, sheltered work has tended increasingly to function as a kind of "holding-space" for the unemployed. Research has

\footnotetext{
32 Transfer within the sheltered workshops themselves does not exceed $7 \%$ and results essentially from natural processes (Stoks, 1989, p. 7).

${ }^{33}$ In 1970 the number of WSW employees was 43,508, and 58,311 in 1975.
} 
revealed that, in times of recession, increasing numbers of the economic unemployed, free, that is, from any disability, tend to move into the sheltered workshops (Bruinsma, 1982, pp. 23-26). Workers with a severe handicap thus find it increasingly difficult to achieve minimum productivity levels and either slide back into the B category or are deprived of access to the sheltered workshops altogether.

The increase in the number of WSW beneficiaries has been accompanied by rising costs and it is for this reason that, since 1984, the government has pursued a policy of curtailment. Under this policy, restrictions have been placed on local authorities regarding the growing number of WSW jobs available. The policy was in fact intended to reduce the number of WSW beneficiaries by 1987, in both categories A and B, by close on $6 \%$. A reduction was indeed achieved: from 81,302 in 1984 to 77,801 in 1987 . The category B figure had already begun to fall in 1981 when it was 4,235 to reach 2,690 in 1988. As a result the share of B beneficiaries in the total fell from $5.5 \%$ in 1981 to $3.4 \%$ in 1988 (see Table 4).

\subsection{New measures}

In practice the policy of curtailment caused widespread dissatisfaction; it was felt by local authorities to be too rigid, making any attempt to adjust to local conditions impossible. Moreover, this policy resulted in waiting-lists. In 1986, approximately 9,000 were awaiting placement in sheltered workshops and by 1989 the average number of those on the list for placement was $10,350.34$

This situation called for emergency measures. In 198810 million florins were set aside to defray the cost of implementing this policy. Consequently, local authorities with long waiting-lists and with relatively low exit rates were allowed to exceed the prescribed growth percentages, which caused the number of WSW employees in 1988 to reach 78,366.

Early in 1989, the law was changed and a system of budget financing, using a base-year method, was introduced, 1985 being the year chosen for the 1989 and 1990 budgets. This means that the sheltered workshops must now do with the funds they appear to have required in previous years (3.2 milliards per year) instead of operating on the basis of "open" funding as they had been doing to date. In 1991, this system is due to be replaced by budget financing based on objective parameters. Should there be a short-fall at the end of the year, the state will no longer make up the difference and the local authorities themselves will have to step in. This change in the method of financing has made the management of sheltered workshops more market-oriented in approach. To a greater extent than hitherto, attention will, as a result, tend to focus on commercial performancy and only afterwards on humanitarian considerations. The consequence of this may well prove to be an increase in turn-over and a fall in absenteeism (Stoks, 1990). With the introduction of budget financing, the curtailment policy has been abandoned.

In addition to tighter financial control, another aim has been decentralisation. Here the idea has been to give local authorities the greatest possible leeway in implementing the law so as to reflect local or regional needs and conditions. Abandoning the curtailment policy will lead to some increase in the number of jobs available, although the latter will be limited by budgetary restraints. Consideration is also being given to the possibility of using

${ }^{34}$ Given that different concepts were used in deriving these figures, no conclusion can be drawn concerning waiting-list trends over time. 
performance targets as a way of promoting the transfer of employees from the sheltered workshops to open employment on the labour market outside. One way of achieving this might be to increase the opportunities for job placement in open employment by secondment. Another idea is to grant WSW undertakings a compensation award of 10,000 florins for every beneficiary transferring to the normal work process. ${ }^{35}$ Such transfers could, moreover, be promoted by obliging WSW undertakings to terminate a beneficiary's employment immediately an adapted job becomes available on the open market. ${ }^{36}$ Should the new adapted occupation pose problems, the beneficiary concerned could within the year be allowed to return to his former sheltered workshop. Thought is also being given to the idea of creating opportunities for temporary employment within the WSW programme as a way of facilitating prospective transfers. There is in addition a proposal for experimenting with arrangements for persons who, because of a worsening of their handicap, risk being no longer able to attain the minimum productivity level. Ways must be devised for preserving the occupational capacity of such persons for as long as possible. ${ }^{37}$

Finally, a broadening of the WAGW beneficiary group to include WSW employees, and proper implementation of this law, could well increase the chances of sheltered employees integrating in the normal work process. In the prevailing situation of high unemployment, however, increasing this transfer rate will doubtless be no easy task. Budget financing, commercialisation and the consequent need for profit have had the negative result of keeping the weakest outside the sheltered system altogether, and of eliminating category B beneficiaries. Their share in the WSW programme has fallen in recent years by $40 \%$ (see Table 4). Some suggest that disabled persons unable to attain $30 \%$ of a given productivity standard do not properly belong to the WSW programme and should be placed in homes. ${ }^{38}$ The question must however be asked whether such a solution would not prove even more expensive. As to the category of the mentally handicapped within the WSW system, it is currently estimated that some $2,900(12 \%)$ are at, or below, the minimum productivity level. It is likewise estimated that 2,000 of these will in time be no longer able to achieve even this minimum as a result of diminishing capacity and would be better placed in homes. The current policy in this connection has been to optimise the use made of WSW vacancies and there are even plans to open the doors of the sheltered workshops to the long-term unemployed. Productivity will as a result increase but it is also clear that the original purpose of these workshops will begin to disappear. Employers have criticised these developments as constituting a distortion of competition (Stoks, 1989, p. 7); others have suggested that the productivity criterion is discriminatory, for, in principle, every motivated disabled individual should be entitled to a place in a sheltered workshop.

\footnotetext{
${ }^{35}$ This is in respect of employees transferring over the period July 1990 to June 1991; after that date an increase will be awarded when the number of transferring employees exceeds the average.

${ }^{36}$ The same also applies when a WSW employee is no longer able to work regularly, or when the performance of an occupation is no longer conducive to the latter's well-being.

${ }^{37}$ For the relevant proposals, see memorandum by the secretary of state SCW of 18 May 1990, Official Gazette 1990, 99; PS (parliamentary documents) 1990, p. 870.

${ }^{38}$ Residences for the adult physically and mentally disabled concern persons who no longer need to be placed in homes for prolonged periods, but who are not as yet (or no longer) able to work in sheltered workshops or in open employment in the private sector; these residences are funded by the general law on special medical costs (AWBZ).
} 


\section{Conclusion}

The Dutch policy of preserving, restoring and promoting the participation of disabled persons in the normal work process stems not only from a concern for the well-being of the disabled but also from the need to reduce the number of occupational disability beneficiaries. This could be done by limiting the AAW and WAO entrance and exit rates. The WAGW and WSW are the legal instruments for achieving this end, and both laws are based on the right to equal opportunity in training and employment.

From this it may be deduced that the purposes of the Dutch integration policy are to some extent contradictory. The policy thusfar pursued in the Netherlands has in the first place given rise to discrimination within the disabled community and has made little or no contribution to the purpose of equal opportunity in the employment for which such disabled persons are qualified. Achievement of this second purpose has been made more difficult by the fact that the policy of the authorities, the placement agencies and employers is above all focused on limiting the WAO entrance rate. Similarly, the WSW programme continues to lay great stress on limiting or improving the quality of entrances. Raising the exit rate has merited little or no attention, even though the increase in the number of beneficiaries is clearly due to exits lagging behind entrances for structural reasons. ${ }^{39}$ The most effective policy is a successful reinsertion policy, for it is only in this way that the financial burden is limited and the income situation of those concerned can be given optimal guarantees (Delsen and Bemelmans, 1987).

In our view, a policy for reintegration will only be successfull if it seeks to adapt the individual and his occupational capacity to the work to be done, and not the reverse. If reintegration of the disabled is to be at all successful, one must start with the individual, stressing the latter's potential and not his inabilities or handicaps. The disabled must be looked upon as having potential for all kinds of work, in the light not only of their skills and capacities but also of their interests. As a result, persons with identical physical and mental impairment may be found in a wide range of professions and occupations, from the highly skilled to the unskilled. It is also conceivable that the same job may be performed by different persons suffering from very different disabilities (Delsen, 1989).

The solutions put forward in Dutch legislation on occupational disability for stemming undesirable trends in cost and volume have laid increasing stress on financial considerations - one need only think, for example, of the reduction in the level and length of benefit brought about by the introduction of more stringent selection criteria. But that is not all, other measures have come into force or are in preparation: a system of rewards and penalties, a raising of the disability threshold for elegibility for benefit, a reduction in the sickness allowance after six weeks, the introduction of a quota obligation, and, for the WSW, budget financing standards, decentralisation and deregulation. One important objection to such measures is that they also hit hard at people for whom a WAO or AAW benefit, or a job in the WSW programme, is the only solution. And some thought at least should be given to the mentally handicapped who may well be the ones left to pick up the bill. Not a great deal has been said about their interests. If the existing system is to be improved, adopting an

39 Acording to Mr L. Schunck, director of the standard sheltered workshop "Stichting Maastrichtse Toeleverings Bedrijven", employing more than 1000 workers, the sheltered workshop is a necessary evil born of our affluent society "which hides away these more vulnerable groups instead of integrating them into the "mainstream of social life"" (Stoks, 1989, p. 5). 
active labour-market policy may be the best solution. Sweden is a case in point. Sweden's success in achieving full employment and a high level of labour force participation has been due in large measure to its active labour-market policy. Long-term unemployed is thus avoided. Of the total expenditure on labour-market policy pursued by that country is not lower than in other European countries, only $30 \%$ is devoted to unemployment benefit, the remaining $70 \%$, approximately, being used to finance the active labour-market policy. The converse applies in most other European countries, including the Netherlands. It might therefore be argued that while Sweden invests in competence, other countries invest in unemployment. Indeed, in that country the right to work predominates, while in most of the other European countries it is the right to income that takes precedence. Moreover, total expenditure on labour-market policy as a percentage of GDP in Sweden is lower than in the Netherlands.

A more active labour-market policy -incorporating, among other things, a programme for reintegration - would thus appear to be the best way of obviating and reducing longterm unemployment. 40 Training and retraining programmes must necessarily be a part of any such policy (Delsen and Van Veen, 1992). In general terms, the training level of disabled persons is lower than that of the labour force as a whole; training becomes therefore a key instrument in the job placement of the disabled. Not only does it increase their chances of access to the labour market, but it also becomes an important tool for reducing the negative effects of their handicap, thus optimising their chances of success in the struggle for employment.

40 The position of disabled workers in the labour market is generally extremely weak; various studies in Europe reveal that not only the level, but also the length of unemployment among the disabled are above those of the labour force in general (Delsen and Bemelmans, 1987). 


\section{REFERENCES}

BAX, E. H., (1984), Maatschappelijke verandering en arbeidsongeschiktheid. De macro-determinanten van WAO-toetredingen uittreding nader verkend. Ministerie van Sociale Zaken en Werkgelegenheid, Den Haag.

BOSCH, F. A. J., and van den en PETERSEN, C., (1983), Aspecten van ziekte en arbeidsongeschiktheid in het stelsel van sociale zekerheid, Deventer.

BRUINSMA, G., (1982), “Werkt de WSW?”, De Toorts, Haarlem.

DELSEN, L. , (1989), Improving the employability of the disabled: A practical approach, International Journal for the Advancement of Councelling, Vol. 12, No. 2, pp. 125-135.

DELSEN, L., and BEMELMANS, Y., (1987), Gehandicapten aan het werk, Presses Interuniversitaires Européennes, Maastricht.

DELSEN, L., and van VEEN, T., (1992), The Swedish model: partially relevant for other European countries, British Journal of Industrial Relations, April (in press).

Gemeentelijke Medische Dienst, Jaarverslagen, Amsterdam.

KLOSSE, S., (1990), Menselijke schade, vergoeden of herstellen, de werking van (re)integratieregelingen voor gehandicapten in de Bondsrepubliek Duitsland en Nederland, Antwerpen/Apeldoorn.

MERENS-RIEDSTRA, H. S., (1983), Leven zonder werk, Deventer.

Ministerie van Sociale Zaken en Werkgelegenheid, (1989), Sociale Werkvoorziening. Resultaten van het onderzoek naar het werknemersbestand per ultimo december 1988, Den Haag.

STOKS, F., (1989), Sociale werkplaatsen in zaken, Intermediair, 25e jaargang, 10 februari, pp. 5-7.

STOKS, F., (1990), Sociale werkplaatsen voor robots, Intermediair, 26e jaargang, 9 maart, p. 11. 